\title{
Mandibular gland pheromone contents in workers and queens of Apis mellifera adansonii
}

\author{
Abdullahi A. Yusuf, Christian W. W. PIRK, Robin M. Crewe \\ Social Insects Research Group, Department of Zoology and Entomology, University of Pretoria, Private Bag X20, \\ Hatfield 0028, Republic of South Africa
}

Received 9 May 2014 - Revised 29 November 2014 - Accepted 12 December 2014

\begin{abstract}
Secretions from the mandibular glands of honeybees have been studied extensively, with those of queens dominated by $\omega-9$ fatty acids and $\omega-10$ fatty acids dominating those of non-laying workers. Apis mellifera adansonii (Latreille) is one of the widely distributed subspecies of African honeybees. However, its mandibular gland pheromones have not been analysed previously. Using gas chromatography, we analysed the composition of mandibular gland pheromones in workers and queens of $A$. mellifera adansonii from Nigeria. Qualitatively, workers and queens have similar pheromone profiles to those previously reported in other African subspecies of honeybees. We found 9-ODA and high amounts of its precursor 9-hydroxy-2 (E)-decenoic acid (9-HDA) in workers, thus showing that they produce queen-like signals under queen-right conditions. We also found geographic variation in the pheromone profiles and morphometric characters of these workers, suggesting different pheromone and morphoclusters from the different ecological and climatological regions inhabited by $A$. $m$. adansonii in Nigeria.
\end{abstract}

\section{African honeybees / queen-right / mandibular gland secretions / pheromone clusters / morphoclusters}

\section{INTRODUCTION}

Social organisation driven by reproductive dominance is a key characteristic of eusociality in insects. In honeybees, this is mainly controlled through effective communication between the queen and workers in the colony. The honeybee colony provides a locale in which cues, ranging from the temperature produced by active workers in the brood nest (Basile et al., 2008) to brood pheromones emitted by the open brood (Le Conte et al., 1990) and glandular secretions (especially those from the mandibular glands relating to reproductive dominance Crewe and Velthuis, 1980), can interact and determine responses by the members of the colony.

Corresponding author: A. Yusuf, aayusuf@zoology.up.ac.za

Manuscript editor: Peter Rosenkranz
Queen pheromone components function primarily to keep the colony in a queen-right condition by signalling the presence of a viable queen to other workers throughout the colony or over short distances. Chemical signals from the mandibular gland secretions of honeybee queens (Apis mellifera) have been implicated in the control of behavioural and physiological activities such as eliciting retinue behaviour among workers (Slessor et al., 1988), inhibiting emergency queen rearing as well as ovary activation in workers (Butler, 1959). The constituents of this gland have been studied in detail, and the active components identified as methyl $p$-hydroxybenzoate, 9-oxo-2 $(E)$-decenoic acid (9-ODA) (which constitutes about $80 \%$ of the secretions in mated queens), 4-hydroxy-3-methoxyphenylethanol (HVA), $(R, E)$-9-hydroxy-2-decenoic acid (9-HDA), $(S, E)$-9-hydroxy- 2-decenoic acid (9-HDA), 10hydroxy-decanoic acid (10-HDAA) and 10hydroxy-2 $(E)$-decenoic acid (10-HDA) (Slessor et al., 1988; Winston et al., 1989). 9-ODA, the two 
enantiomers ( $R$ and $S$-9HDA) and the two aromatic compounds (HOB and HVA) are referred collectively as the queen mandibular pheromones (QMPs) reviewed in Pirk et al. (2011). These five compounds act together to maintain reproductive dominance and elicit worker retinue behaviour. Keeling et al. (2003) identified four other components that are not of mandibular gland origin, namely methyl $(Z)$-octadec-9-2-en-1-o 1 (methyl oleate), (E)-3-(4-hydroxy-3-methoxyphenyl)prop-2-en-1-o 1 (coniferyl alcohol), hexadecane1-o 1 and (Z9, Z12, Z15)-octadeca-9, 12, 15trienoic acid (linolenic acid), which act in synergy with QMPs to elicit retinue behaviour. This leads to a terminology shift from QMP to queen retinue pheromones (QRP) (Slessor et al., 2005). In addition, the mandibular glands of non-laying workers produce large amounts of $(E)$-10-hydroxy-2decenoic acid (10-HDA) known as worker substance, which is also found in royal and worker jellies and has been implicated in queen determination in larvae (Spannhoff et al., 2011).

Africa is home to 10 (Hepburn and Radloff, 1998) or 11 (Ruttner, 1988) morphoclusters (subspecies) in the Apis mellifera complex that have distinct geographic distributions and morphologies. However, we only know the composition and spectrum of the mandibular gland fatty acids from four subspecies, i.e. capensis, scutellata, intermissa and saharensis (Crewe, 1982; Crewe and Moritz, 1989; Hepburn and Radloff, 1996). This knowledge has shown that the composition of pheromone bouquets from queens and workers is subspecies specific, especially in relation to the ability of Apis mellifera capensis workers to become facultative social parasites and mimic the pheromone bouquet of queens in their host colonies (Crewe and Velthuis, 1980). Such variation in the composition of an important primer and releaser pheromone which affects both worker and queen behaviour in the hive needs to be understood not only in races of African honeybees but also in other races. An understanding of these differences is important for the management and conservation of different races of honeybees on which sustainable apicultural practices will be dependent.

The West African honeybee A. mellifera adansonii (Latreille) is found along the West African coast of Senegal, Chad, Nigeria, far south
Cameroon (Hepburn and Radloff, 1998), the Congo basin as well as Angola to the South (Ruttner, 1988). This makes it one of the two subspecies with the widest geographic range among African subspecies. However, despite its wide distribution and being the first African subspecies described by Latreille (in Ruttner (1992)), there is no information on the chemistry and composition of mandibular gland pheromones in A. mellifera adansonii from any of its native range.

To gain an insight into its chemical signals and how these vary along an ecological gradient, we compared the mandibular gland pheromone composition of $A$. mellifera adansonii queens and workers from different regions of Nigeria. We sampled workers from three regions and queens from two regions of Nigeria (North West (Sudan savannah), North Central (Guinea forest savannah) and South West (rainforest)) to examine the variation in mandibular gland pheromone composition as well as bee morphology across these ecological zones. We hypothesise that mandibular gland pheromones in both workers and queens of $A$. mellifera adansonii will be the same to those of the A branch of the mellifera complex (Ruttner 1988) especially Apis mellifera scutellata. In addition, we expect that there will not be any geographic variation in the proportions and amounts of $A$. mellifera adansonii mandibular gland pheromones and morphometric characters across Nigeria.

\section{MATERIALS AND METHODS}

\subsection{Honeybees}

WorkersWorkers (total=383) of A. mellifera adansonii were sampled from frames in 30 queen right colonies from apiaries at Jaja $\left(11^{\circ} 15^{\prime} \mathrm{N}, 07^{\circ} 39^{\prime} \mathrm{E}\right)$, Tashar Fulani $\left(11^{\circ} 17^{\prime} \mathrm{N}, 07^{\circ} 40^{\prime} \mathrm{E}\right)$, Shika Dam $\left(11^{\circ} 08^{\prime} \mathrm{N}\right.$, $\left.07^{\circ} 40^{\prime} \mathrm{E}\right)$, Unguwan Dan Asabe ( $\left.11^{\circ} 09^{\prime} \mathrm{N}, 08^{\circ} 20^{\prime} \mathrm{E}\right)$, Zabi $\left(11^{\circ} 18^{\prime} \mathrm{N}, 07^{\circ} 43^{\prime} \mathrm{E}\right)$ in Zaria, Kaduna State (North West), a commercial apiary in Roguwa $\left(08^{\circ}\right.$ $\left.49^{\prime} \mathrm{N}, 07^{\circ} 43^{\prime} \mathrm{E}\right)$ Keffi, Nasarawa State (North Central) and two apiaries from Iwo $\left(07^{\circ} 33^{\prime} \mathrm{N}, 04^{\circ} 11^{\prime} \mathrm{E}\right)$ and Osun and Ijebu-Ode $\left(06^{\circ} 46^{\prime} \mathrm{N}, 03^{\circ} 56^{\prime} \mathrm{E}\right)$ Ogun States (South West), Nigeria (Figure 1) between December 2011 and January 2013. The colonies sampled were from sites characterised by stationary smallholder operations. The workers were randomly sampled, placed in 


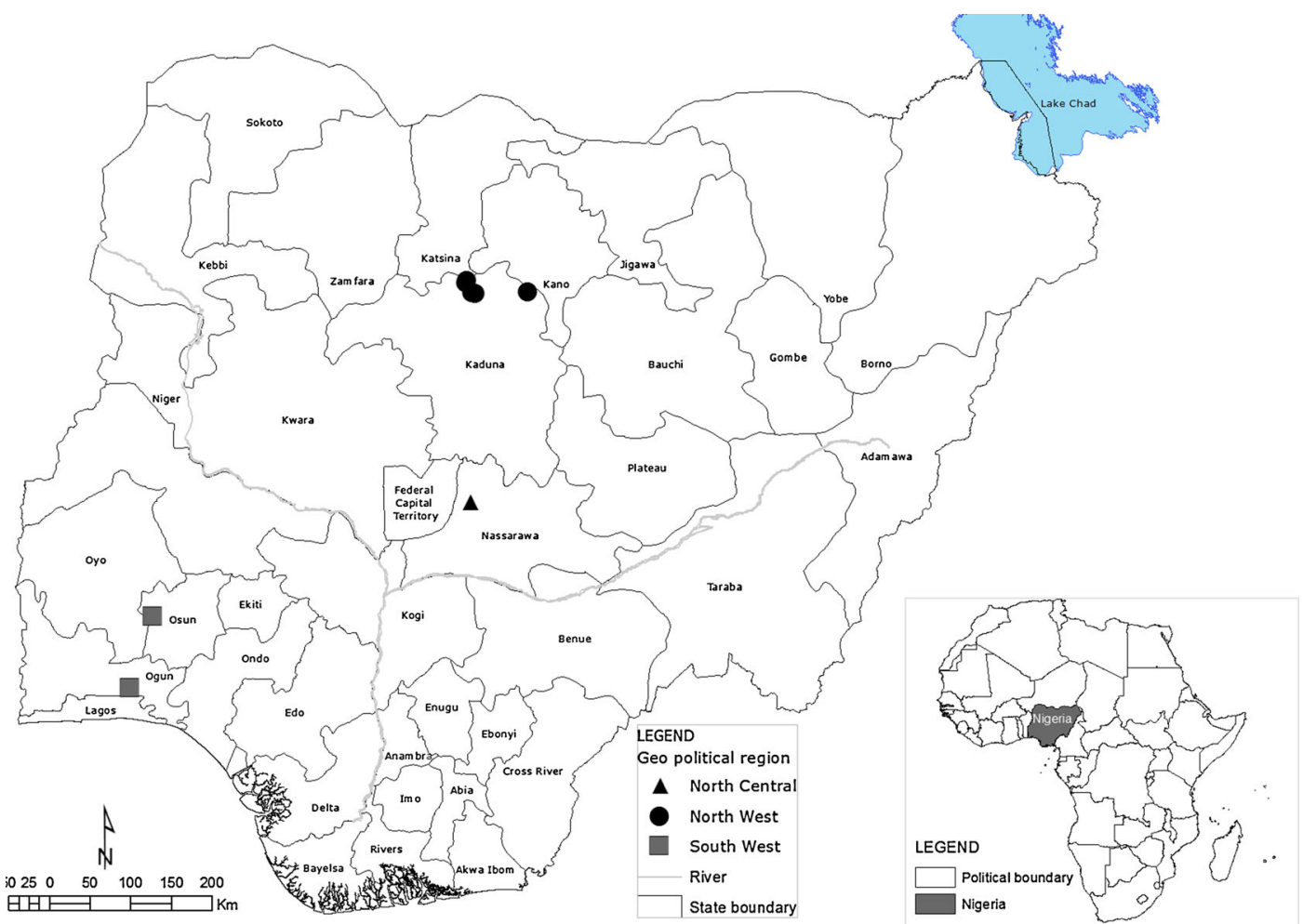

Figure 1. Map of Nigeria showing apiaries where samples were collected from Jaja, Tashar Fulani, Unguwar Dan Asabe in Zaria Kaduna state North West (circles ); Roguwa, Keffi Nasarawa state North Central (triangle); and Iwo Osun state and Ijebu-Ode, Ogun state South West (squares) Nigeria.

clean labelled, perforated plastic vials and immobilised on ice. The heads were then decapitated and placed into a clean $2 \mathrm{~mL}$ vial containing dichloromethane (ChromSolv ${ }^{\circledR}$ grade for HPLC Sigma-Aldrich, St. Louis, MO, USA) and refrigerated until analysis.

Queens Naturally mated, egg laying queens were sampled from 17 colonies (13 from North West and 4 from North Central) in apiaries where queen rearing and controlled mating were not practised. Unfortunately, no queens were collected from apiaries in the South West since the beekeepers were reluctant to sacrifice their queens. Queens were collected from colonies, and the heads sampled in a similar way as described for workers above.

\subsection{Extraction of mandibular gland pheromones from heads}

Heads were extracted in $200 \mu \mathrm{L}$ of dichloromethane (HPLC grade, Sigma-Aldrich) following the methods described in the studies of Dietemann et al. (2006) and Zheng et al. (2010). Prior to gas chromatography, each extract was divided into two and half was stored as a backup for further analysis or confirmation (if need be). The other half $(\sim 100 \mu \mathrm{L})$ was transferred into a vial and evaporated to dryness under a gentle stream of charcoalfiltered nitrogen gas. The residue was then re-dissolved in $10 \mu \mathrm{L}$ of internal standard solution (containing $1 \mathrm{mg}$ of octanoic acid and $1 \mathrm{mg}$ of tetradecane in $4 \mathrm{ml}$ dichloromethane) to which $10 \mu \mathrm{L}$ of bis-(trimethylsily) trifluoroacetamide (BSTFA) was added to derivatise the fatty acids.

\subsection{Gas chromatography}

One microlitre of the derivatised extract from above was injected in splitless mode into an Agilent 6890 gas chromatograph fitted with a $25 \mathrm{~m} \times 0.20 \mathrm{~mm} \times 0.33 \mu \mathrm{m}$ HP1-methyl silicone-coated fused silica capillary column and an FID detector. The carrier gas was helium at a flow rate of $1 \mathrm{~mL} / \mathrm{min}$ and oven temperature-programmed as 
follows: $50{ }^{\circ} \mathrm{C}$ at $50{ }^{\circ} \mathrm{C} / \mathrm{min}$ to $100^{\circ} \mathrm{C}$, then increased at $3{ }^{\circ} \mathrm{C} / \mathrm{min}$ to $220^{\circ} \mathrm{C}$ and then held at $220^{\circ} \mathrm{C}$ for $10 \mathrm{~min}$ (modified after Simon et al., 2001; Dietemann et al., 2006; Tan et al., 2012). Chromatograms were recorded and the peak areas quantified using Chemstation ${ }^{\circledR}$ software. Six of the major components from mandibular glands of honeybees that had been shown to elicit both behavioural and physiological responses (namely methyl p-hydroxybenzoate, 9-oxo-2 (E)-decenoic acid (9ODA), 4-hydroxy-3-methoxyphenylethanol (HVA), 9hydroxy-2 $(E)$-decenoic acid (9-HDA), 10-hydroxydecanoic acid (10-HDAA) and 10-hydroxy-2 (E)decenoic acid (10-HDA)) were identified based on comparison with retention times of synthetic standards. Quantification was achieved by comparing the relative mass ratios (RMR) of each of these compounds in a standard solution mixture (containing $\sim 1 \mathrm{mg}$ of each in $4 \mathrm{~mL}$ dichloromethane) relative to the RMR of tetradecane. We did not separate the enantiomers of 9HDA in our analysis and, therefore, reported both enantiomers together throughout the study. As a check for shifts in retention times of compounds between GC runs, standard mixtures were run before each batch of head extracts and then after every 25 to 30 samples. All standards and reagents with the exception of 9-ODA and 9-HDA (PheroTech Inc.) were obtained from Sigma-Aldrich.

\subsection{Morphometrics}

Ten worker bees (not those used for pheromone analysis) were sampled from each of the 30 colonies used in this study. The bees were preserved in $90 \%$ ethanol and later dissected according to the methods of Ruttner (1988). The following seven morphometric characteristics based on the Oberursel standard list (Ruttner, 1988) were measured: forewing length (FL), forewing width (FW), hindwing length (HL), hindwing width (HW), proboscis length (PL), number of landmarks on the forewing (NF) and number of landmarks on the hindwing $(\mathrm{NH})$ were measured. All together, 300 worker bees were analysed and the values expressed in millimeters, except for NF and $\mathrm{NH}$ which were count data.

\subsection{Statistical analyses}

Since data for both percentage composition and amounts were not normally distributed, non-parametric statistical tests were applied. Kruskal-Wallis ANOVA (KWA) and median test with multiple comparisons were applied to determine differences in the individual as well as total MDG components in workers between regions, with regions as the independent (grouping) variable and the MDG components as dependent variables. Since no queens were sampled from South West, a Mann-Whitney $U$ test (MWU) was used to test for significance in MDG components between queens from North Central and North West. Cluster analyses (Johnson and Wichern, 1998) were performed using the means for both proportions and amounts of pheromones in order to determine the linkage/Euclidean distances between workers from the three regions. Multivariate statistical analyses, including principal component analysis, canonical analysis and linear discriminant analysis, were employed on the morphological characters to classify colonies in relation to their geographic region. The population means between groups were compared using Wilk's lambda test and its distribution approximated by the $F$ distribution (Johnson and Wichern, 1998). Results unless otherwise stated are presented as means \pm the standard errors of the mean. All statistical tests were carried out using the software STATISTICA 12 (StatsSoft Inc. USA), and $\alpha$ was set at 0.05 .

\section{RESULTS}

\subsection{Proportion of MDG components in workers and queens}

The proportions of the major MDG components from the head extracts of workers and queens of $A$. mellifera adansonii are presented in Figure 2(a (i), a (ii)) respectively. All the major components with the exception of HVA were present in workers, with 10-HDA and its precursor 10-HDAA dominating the profile at $43.49 \pm 1.22$ and 23.99 $\pm 0.87 \%$, respectively, followed by $\mathrm{HOB}$, 9HDA and 9-ODA respectively. The average proportions of 9-ODA and 9-HDA that are the major components of queen signals were $17.26 \pm 0.83 \%$ [Figure 2(b (i))].

In the case of the queens, all six major and behaviourally active MDG components were 

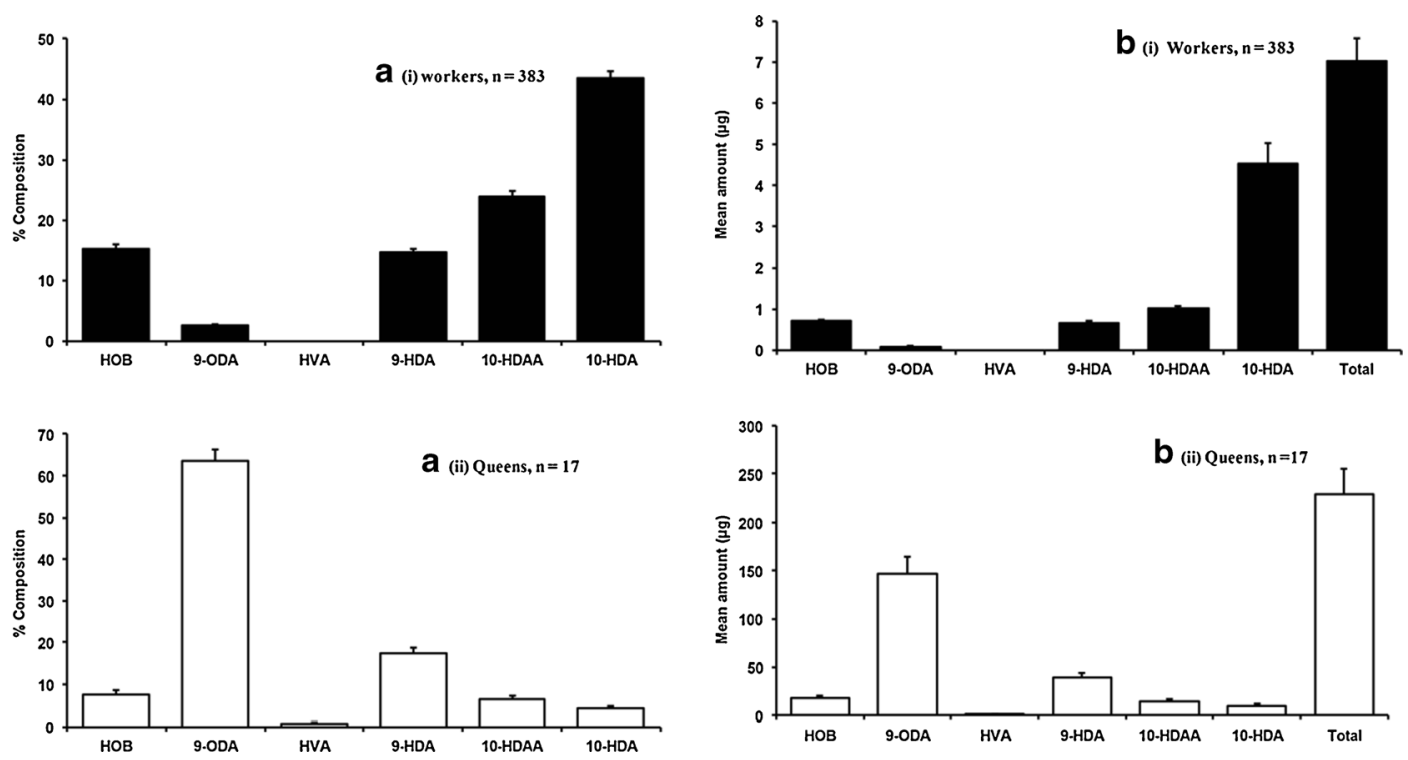

Figure 2. Percentage composition $(a)$ and amount $(\mu \mathrm{g})(b)$ of mandibular gland pheromones in workers (black bars) and queens (open bars) of Apis mellifera adansonii. Please note the differences in scales for workers and queens of the amounts in micrograms. Mandibular gland components are: $\mathrm{HOB}=p$-hydroxybenzoate, 9-ODA=9oxo-2 (E)-decenoic acid, HVA=4-hydroxy-3-methoxyphenylethanol, 9-HDA=9-hydroxy- $2(E)$-decenoic acid, 10-HDAA=10-hydroxy-decanoic acid and 10-HDA=10-hydroxy-2 $(E)$-decenoic acid. Error bars are standard errors of the means, $n=$ number of samples.

present. The 9-ODA was the most abundant at $63.64 \pm 2.74 \%$, followed by its precursor 9HDA, HOB, then the two worker components 10-HDAA and 10-HDA, with HVA as a minor component [Figure 2(a (ii))].

\subsection{Absolute amounts of MDG components in workers and queens}

Absolute amounts were very variable in the mandibular glands of workers [Figure 2(b (i))] with total absolute amounts averaging $7.0 \pm 0.55 \mu \mathrm{g}$ per bee. Even though the worker component 10-HDA was highly variable at $4.53 \pm 0.49 \mu \mathrm{g}$, it was the most abundant component in the mandibular glands of workers. This was followed by its precursor 10-HDAA $(1.03 \pm 0.06 \mu \mathrm{g})$, HOB $(0.71 \pm 0.04 \mu \mathrm{g})$ and some queen substance 9-ODA $(0.09 \pm 0.01 \mu \mathrm{g})$ and its precursor 9HDA $(0.66 \pm 0.05 \mu \mathrm{g})$.

In queens, the total absolute amount was $229.37 \pm 25.54 \mu \mathrm{g}$ per queen with 9-ODA at the level of $146.44 \pm 17.74 \mu \mathrm{g}$, its precursor 9-HDA $(39.17 \pm 5.09 \mu \mathrm{g})$ with HVA as the minor component at $1.54 \pm 0.28 \mu \mathrm{g}$ [Figure 2(b (ii))].

\subsection{Regional variability in the pheromone profiles of workers}

Results from the three regions (North Central, North West and South West Nigeria, Table I) showed that the proportions of 9-ODA, 9-HDA, 10-HDAA and 10-HDA were different (KWA: H $(2, N=383), P<0.05)$ while that of HOB were not significantly different (KWA: H $(2, N=383)$, $P=0.3495$ ) irrespective of the region sampled. Profiles of workers from South West had the most (54.42 $\pm 1.62 \%$ ) 10-HDA (workers substance) in comparison to those from North Central and North West respectively (Table I). Interestingly, those workers from the North West and North Central had proportionally more of the queen substance 9-ODA and its precursor 9-HDA compared to those from the South West (Table I). Based on the mean proportions of their 
Table I. Relative proportions (mean $\pm \mathrm{SE}$ ) of mandibular gland pheromones from head extracts of Apis mellifera adansonii workers and their differences between the North Central (NC), North West (NW) and South West (SW) regions of Nigeria.

\begin{tabular}{|c|c|c|c|c|c|}
\hline Compounds & $\begin{array}{l}\text { North Central }(\mathrm{NC}) \\
\text { Mean proportion } \pm \mathrm{SE}\end{array}$ & $\begin{array}{l}\text { North West }(\mathrm{NW}) \\
\text { Mean proportion } \pm \text { SE }\end{array}$ & $\begin{array}{l}\text { South West (SW) } \\
\text { Mean proportion } \pm \text { SE }\end{array}$ & $\begin{array}{l}\text { Kruskal-Wallis } \\
\text { ANOVA H, } p\end{array}$ & Differences \\
\hline HOB & $13.24 \pm 1.49$ & $15.9 \pm 1.10$ & $15.04 \pm 0.91$ & $\begin{aligned} \mathrm{H} & =2.103 \\
p & =0.3495\end{aligned}$ & None \\
\hline 9-ODA & $3.83 \pm 0.72$ & $3.30 \pm 0.40$ & $1.27 \pm 0.15$ & $\begin{aligned} \mathrm{H} & =43.470 \\
p & =0.0000\end{aligned}$ & $\begin{array}{l}\text { NC, NW, } \\
\text { SW }\end{array}$ \\
\hline 9-HDA & $15.65 \pm 1.52$ & $16.8 \pm 0.90$ & $11.52 \pm 0.74$ & $\begin{aligned} \mathrm{H} & =18.607 \\
p & =0.0001\end{aligned}$ & $\begin{array}{l}\text { NC, NW, } \\
\text { SW }\end{array}$ \\
\hline 10-HDAA & $23.95 \pm 1.84$ & $28.7 \pm 1.40$ & $17.75 \pm 0.93$ & $\begin{aligned} \mathrm{H} & =24.460 \\
p & =0.0000\end{aligned}$ & $\begin{array}{l}\text { NC, NW, } \\
\text { SW }\end{array}$ \\
\hline 10-HDA & $43.33 \pm 3.26$ & $35.3 \pm 1.70$ & $54.42 \pm 1.62$ & $\begin{aligned} \mathrm{H} & =58.950 \\
p & =0.0000\end{aligned}$ & $\begin{array}{l}\text { NC, NW, } \\
\text { SW }\end{array}$ \\
\hline
\end{tabular}

HOB=p-hydroxybenzoate, 9-ODA=9-oxo-2 (E)-decenoic acid, HVA=4-hydroxy-3-methoxyphenylethanol, 9-HDA=9-hydroxy$2(E)$-decenoic acid, 10-HDAA=10-hydroxy-decanoic acid and 10-HDA=10-hydroxy-2 $(E)$-decenoic acid

pheromones, workers from North Central and North West formed a distinct pheromone cluster from those in the South West (Figure 3).

The variation in absolute pheromone amounts among $A$. mellifera adansonii workers from the three regions is shown in Figure 4. This was significantly different between the regions for all the worker components as well as the total absolute amount (KWA: $\mathrm{H}(2, N=383), P<0.05)$. The pattern of variation shown is in the following order North Central $>$ South West $>$ North West for the amount of 9-ODA, 9-HDA and 10-HDAA, while the amount of HOB, 10-HDA and total amounts decreased in amount in the following order: South West $>$ North Central $>$ North West respectively (Figure 4), thereby exhibiting an upward trend, increasing altitudinally as one travels through the hinterland (i.e. inwards from the South to the



Figure 3. Dendrogram from cluster analysis of the workers from North Central, North West and South West Nigeria based on mean proportions of each chemical from the head extracts showing the two pheromone clusters (one for workers from North Central and North West, and the other for workers from South West). The Euclidean distances are 9.8, 13.7 and 22.8 for North Central, North West and South West, respectively. 
НОВ

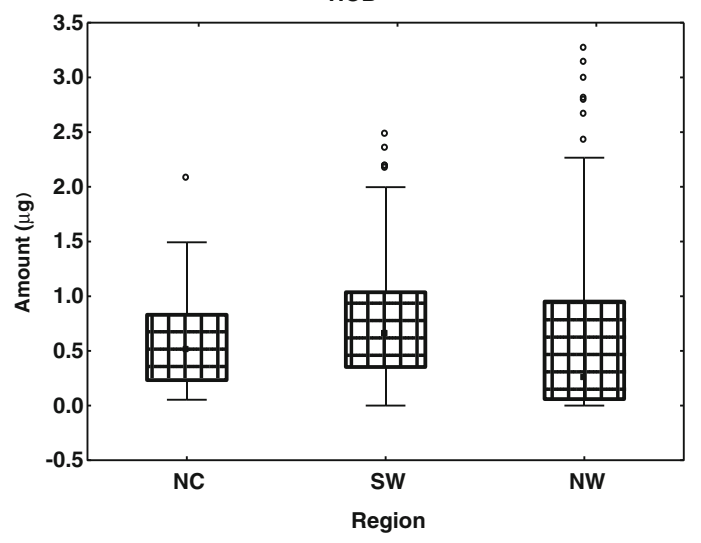

9-HDA
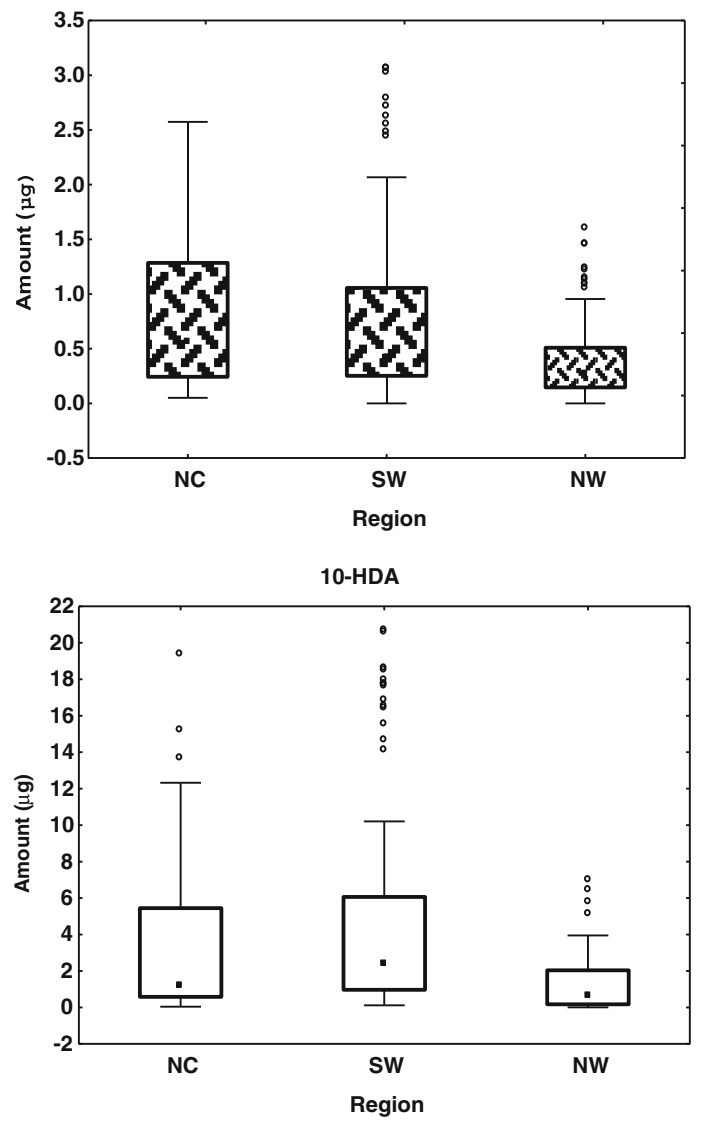

9-ODA

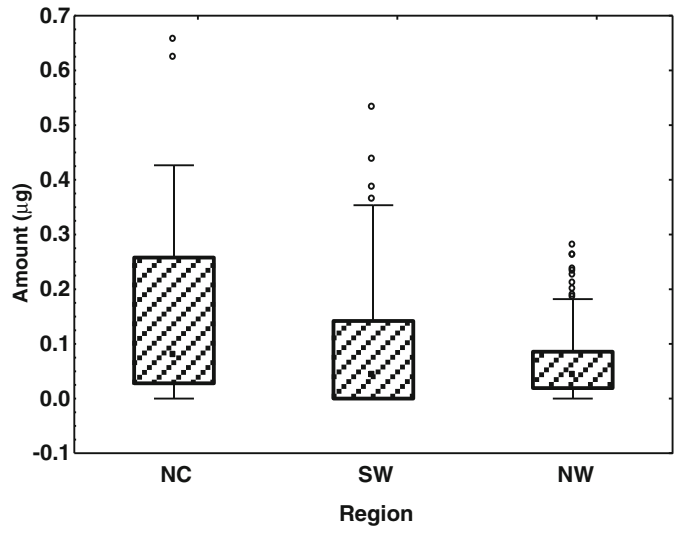

10-HDAA

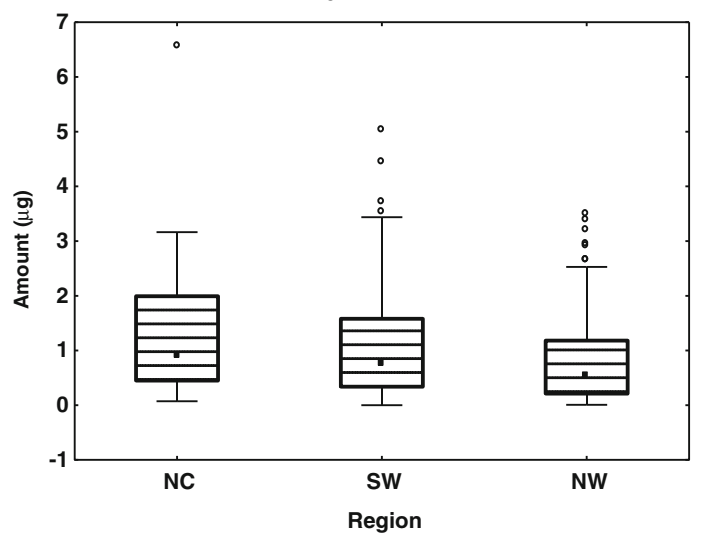

Total

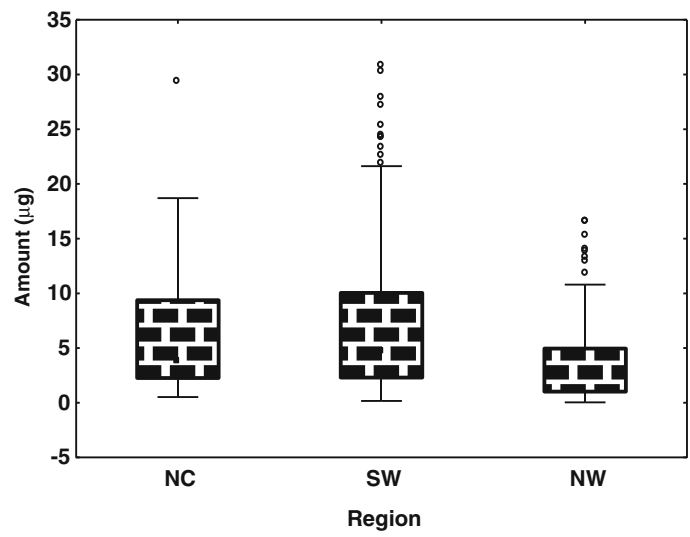

Figure 4. Amount of five major components of the mandibular gland pheromones (HOB, 9-ODA, 9-HDA, 10-HDAA and 10-HDA) and total absolute amounts in workers of A. mellifera adansonii from three geographical regions of Nigeria. $N C$ North Central $(n=45), S W$ South West $(n=145), N W$ North West $(n=193)$. $=$ median, $\square=1$ st and 3rd quartiles, $I=$ non-outlier range (minimum and maximum), $\bigcirc=$ outliers.

North; see Figure 1). Mean total absolute amounts were $9.33 \pm 1.15 \mu \mathrm{g}$ per bee for South West, 6.93 $\pm 1.18 \mu \mathrm{g}$ for North Central and $5.31 \pm 0.73 \mu \mathrm{g}$ per bee from North West respectively. A cluster 


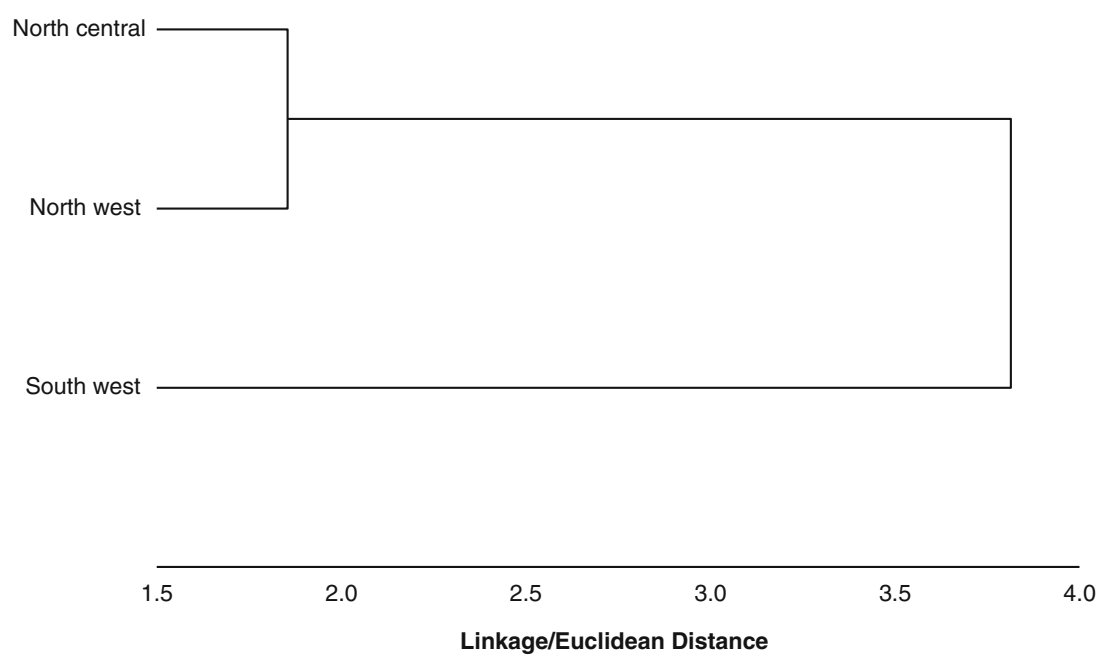

Figure 5. Dendrogram from cluster analysis of the workers from North Central, North West and South West Nigeria based on mean absolute amounts $(\mu \mathrm{g})$ of each chemical compound and the total amounts from the head extracts showing the two pheromone clusters (one for workers from North Central and North West, and the other for workers from South West). The Euclidean distances are 1.85, 3.81 and 5.29 for North Central, North West and South West, respectively.

analysis on the absolute amounts grouped the workers into two distinct pheromone clusters similar to the one for proportions (Figure 5).

\subsection{Regional variability in the pheromone profiles of queens}

Proportional compositions of the MDGs in A. mellifera adansonii queens were not significantly different (MWU test $P>0.05$ ) between those queens from the North Central and North West (Figure 6). The queen substance 9-ODA, which dominated the pheromone profiles, was $70.12 \pm 9.42$ and $61.6 \pm 2.2 \%$ in queens from North Central and North West, respectively (Figure 6a).

Absolute amounts of the MDG components in queens from the two regions are shown in Figure 6b. No marked differences in the absolute amounts were observed between the queens from different regions. Overall comparisons between the queens showed that 9-HDA (the precursor of the queen substance 9-ODA) was slightly different (MWU test, $Z=-1.9814, P=0.047$ ). However, comparatively queens from North
West possess more MDG pheromones (Figure 6b) with a mean total of 242.44 $\pm 33.96 \mu \mathrm{g}$ per queen to $187 \pm 43.21 \mu \mathrm{g}$ per queen from the North Central.

\subsection{Morphometric analysis}

The measured morphometric characters are shown in Table II. Length of forewing (FL) and the number of landmarks on both fore and hind wings were not different between workers from all regions (KWA, $P=0.119$, 0.2117 and 0.06 respectively). Width of forewings (FW), length of hind wings (HL) and proboscis (PL) were different across all regions (KWA, $P=0.0001,0.0001$ and 0.0002 respectively). By contrast, width of hind wings (HW) only differed in workers from the North West (KWA, $P=0.0007$ ).

The principal component analysis of the morphometric characters for the worker honeybees isolated these five factors: FL, FW, HL, HW and PL, with eigenvalues $>1$ which accounted for $79.59 \%$ of the variance in the data. A stepwise discriminant analysis using the colony means of the morphometric 

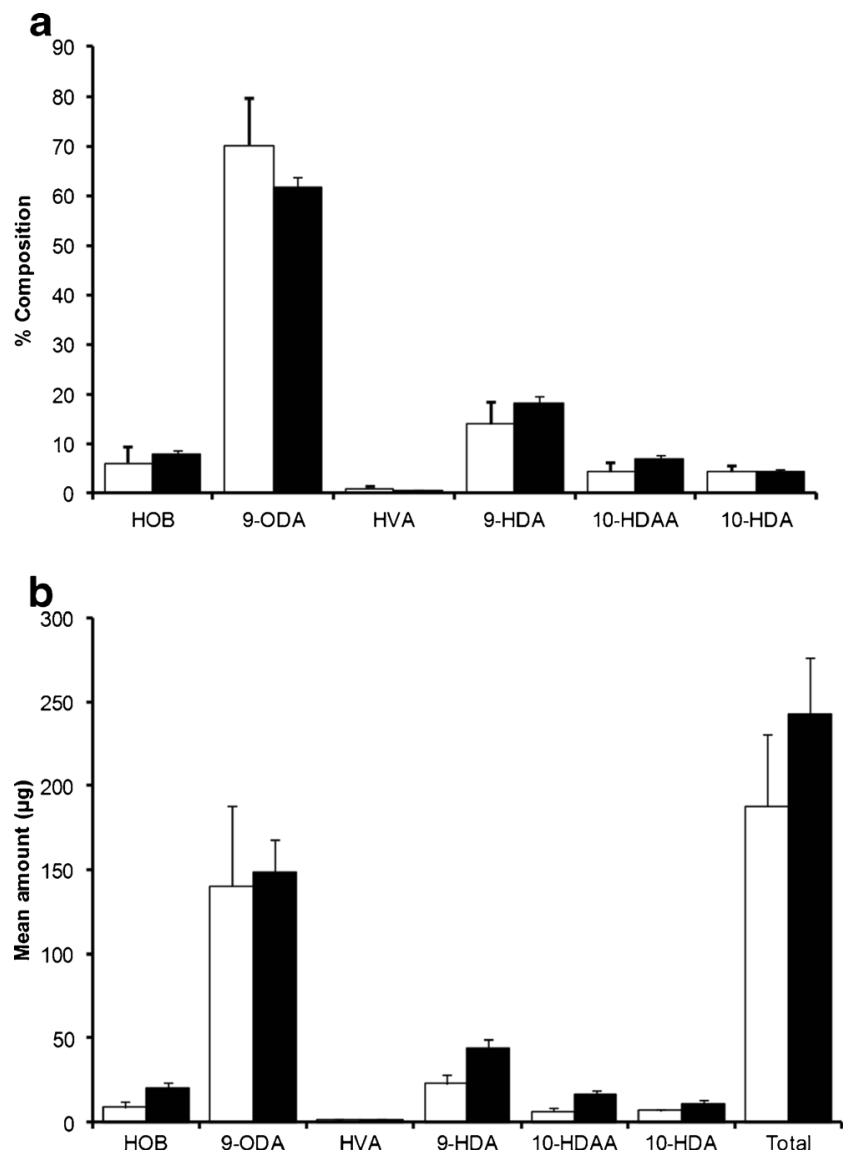

Figure 6. Percentage composition (a ) and mean amount $(\mu \mathrm{g})(\mathbf{b})$ of the individual mandibular gland pheromones from heads of queens of Apis mellifera adansonii from North Central (open bars) and North Western (closed black bars) Nigeria. Mandibular gland components are the following: $\mathrm{HOB}=p$-hydroxybenzoate, 9-ODA=9-oxo-2 $(E)$-decenoic acid, HVA=4-hydroxy-3-methoxyphenylethanol, 9-HDA=9-hydroxy- 2 (E)-decenoic acid, 10-HDAA=10-hydroxydecanoic acid and 10-HDA=10-hydroxy-2 $(E)$-decenoic acid. Error bars represent standard errors of the means.

characters separated the workers into three clusters (Figure 7). From South West, $87.5 \%$ of colonies were classified correctly, with posterior probabilities of $P=1.0$ for seven colonies and 0.08 for one colony (which was incorrectly classified). All colonies from the North Central and North West (100\%) were classified correctly with posterior probabilities of $P=1.0$. Mahalanobis distance $D^{2}$ between the clusters was 132.29 for South West, 66.53 for North Central and 37.93 for North West. Standard coefficient of canonical variance was 95.10, 14.29 (Wilk's lamb$\mathrm{da}=0.0126, \mathrm{~F}(10,46)=36.611, P<0.0001)$.

\section{DISCUSSION}

One of the main findings here is that the mandibular gland pheromone profiles in workers and queens of $A$. mellifera adansonii, a subspecies of African honeybees with a wide distribution range on the African continent, have a high degree of variability. We found in these head extracts all the main and behaviourally active compounds reported earlier from the mandibular glands of different castes in honeybees (Butler, 1959; Slessor et al., 1988; Plettner et al., 1997; Slessor et al., 2005).

The profiles of $A$. mellifera adansonii workers were dominated by 10 -HDA and its precursor 10 - 
Table II. Means and standard errors of measured morphometric characters (lengths are in mm) of A. mellifera. adansonii workers from North Central (NC), North West (NW) and South West (SW) Nigeria.

\begin{tabular}{lccccc}
\hline Character $^{\mathrm{a}}$ & $\begin{array}{l}\text { North Central } \\
\text { (NC) Mean } \pm \mathrm{SE} \\
N=40\end{array}$ & $\begin{array}{l}\text { North West } \\
\text { (NW) Mean } \pm \text { SE }\end{array}$ & $\begin{array}{l}\text { South West } \\
(\mathrm{SW}) \text { Mean } \pm \text { SE } \\
N=80\end{array}$ & $\begin{array}{l}\text { Kruskal-Wallis } \\
\text { ANOVA H, } P\end{array}$ & Differences \\
\hline FL & $6.83 \pm 0.06$ & $6.90 \pm 0.03$ & $6.98 \pm 0.04$ & $\begin{array}{l}\mathrm{H}=4.38, \\
P=0.119\end{array}$ & None \\
FW & $2.17 \pm 0.03$ & $2.45 \pm 0.05$ & $2.27 \pm 0.04$ & $\begin{array}{l}\mathrm{H}=21.11, \\
P=0.0000\end{array}$ & NC, NW, SW \\
HL & $4.68 \pm 0.04$ & $4.98 \pm 0.01$ & $4.83 \pm 0.03$ & $\begin{array}{l}\mathrm{H}=18.37, \\
P=0.0001\end{array}$ & NC, NW, SW \\
HW & $1.32 \pm 0.02$ & $1.37 \pm 0.03$ & $1.31 \pm 0.02$ & $\begin{array}{l}\mathrm{H}=14.62, \\
P=0.0007\end{array}$ & NW \\
PL & $2.62 \pm 0.02$ & $1.79 \pm 0.05$ & $1.46 \pm 0.12$ & $\begin{array}{l}\mathrm{H}=16.88, \\
P=0.0002\end{array}$ & NC, NW, SW \\
NF & $13.00 \pm 0.00$ & $13.00 \pm 0.00$ & $13.00 \pm 0.00$ & $\begin{array}{l}\mathrm{H}=3.05, \\
P=0.2117\end{array}$ & None \\
NH & $6.00 \pm 0.00$ & $6.00 \pm 0.00$ & $6.00 \pm 0.00$ & $\begin{array}{l}\mathrm{H}=5.68, \\
P=0.06\end{array}$ & None \\
\hline
\end{tabular}

${ }^{\text {a }}$ Morphometric characters were explained in the text

$N$ number of workers

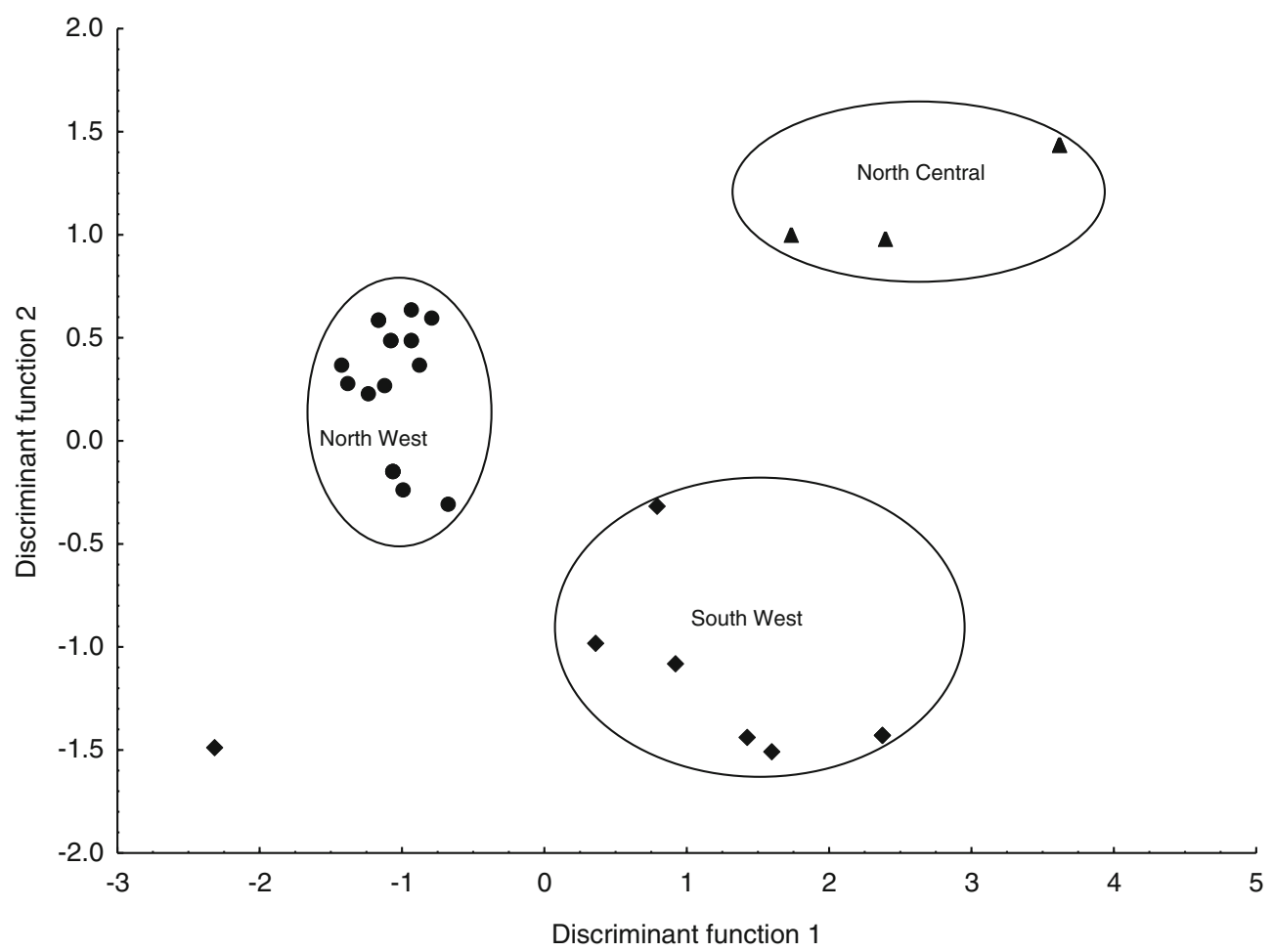

Figure 7. Discriminant analysis plot showing discriminant functions 1 and 2 using the colony means of the morphometric data. Triangles, squares and circles represent workers from North Central, South West and North West Nigeria. Confidence eclipses are drawn at the $95 \%$ level. 
HDAA (Figure 2) similar to subspecies of the A subgroup such as A. mellifera scutellata (Zheng et al., 2010), Apis mellifera intermissa (Crewe and Moritz, 1989) and Apis mellifera saharensis (Hepburn and Radloff, 1996). Interestingly, the amounts of the queen substance (9-ODA) and its precursor (9-HDA) in workers of A. mellifera adansonii were higher than those reported for A. mellifera scutellata (Zheng et al., 2010), A. mellifera intermissa and A. mellifera saharensis (Hepburn and Radloff, 1996), but lower than those for laying workers of A. mellifera capensis (Crewe and Velthuis, 1980) (Table III) and Asian honeybees Apis andreniformis, Apis florea, Apis dorsata (Plettner et al., 1997), Apis cerana and Apis nigrocincta (Keeling et al., 2001). Prior to this study, the ability of workers in African honeybees to produce substantial amounts of 9-ODA under queen-right conditions had only been reported in A. mellifera capensis (Zheng et al., 2010) and A. mellifera intermissa (Crewe and Moritz, 1989) workers and had been implicated in the ability of workers of these subspecies to rapidly develop into laying workers (Ruttner and Hesse, 1981). If we compare the amounts of 9-ODA produced by workers of A. mellifera adansonii with those of both $A$. mellifera capensis and A. mellifera intermissa, we infer that $A$. mellifera adansonii workers are likely to develop into laying workers more slowly than those of $A$. mellifera capensis but faster than those of $A$. mellifera intermissa and
A. mellifera scutellata respectively. However, this needs to be verified experimentally in the case of A. mellifera adansonii .

The presence of substantial amounts of 9-HDA in the head extracts of $A$. mellifera adansonii workers is also of interest since 9-HDA is a precursor of 9-ODA, and high proportions of the two components are referred to as queen-like (Moritz et al., 2004). 9-HDA together with 9-ODA plays an active role in eliciting retinue responses (Slessor et al., 1988), maintaining swarm clusters (Winston et al., 1982), inhibiting queen rearing (Butler and Callow, 1968) and attracting drones (Brockmann et al., 2006). Workers producing queen-like signals in the presence of a queen could pose a threat to social organisation in colonies of other subspecies as seen in A. mellifera capensis workers when they invade colonies of other subspecies, but function effectively in their own colonies (reviewed in the study of Neumann and Hepburn 2002). At this point, we do not know if workers of $A$. mellifera adansonii will exhibit similar behavioural traits.

Queens of $A$. mellifera adansonii are similar in both the composition and absolute amounts of mandibular gland components as those reported for other African subspecies like A. mellifera capensis, A. mellifera intermissa and A. mellifera scutellata (Crewe, 1987), with 9ODA and 9-HDA as the main components, slightly different from the results on Africanized

Table III. Percentage composition of the major components from head extracts of Apis mellifera adansonii, A. mellifera capensis, A. mellifera intermissa, A. mellifera saharensis and A. mellifera scutellata workers. Values are means \pm SD from the mean.

\begin{tabular}{lllcll}
\hline Subspecies & \multicolumn{7}{l}{ Percent composition of major components } & & \\
\cline { 2 - 6 } & 9-ODA & 9-HDA & 10-HDAA & 10-HDA & Reference \\
\hline A. mellifera adansonii & $2.6 \pm 4.9$ & $14.7 \pm 11.3$ & $24.0 \pm 16.9$ & $43.5 \pm 23.9$ & This study \\
$\begin{array}{l}\text { A. mellifera capensis } \\
\text { (laying workers) }\end{array}$ & 76.2 & 7.7 & 0.5 & 5.5 & Crewe \& Velthuis (1980) \\
A. mellifera intermissa & $1.2 \pm 1.4$ & $4.2 \pm 3.4$ & $0.1 \pm 0.3$ & $60.2 \pm 11.3$ & Hepburn \& Radloff (1996) \\
A. mellifera saharensis & $1.7 \pm 1.1$ & $2.6 \pm 0.8$ & $0.4 \pm 1.1$ & $44.0 \pm 10.0$ & Hepburn \& Radloff (1996) \\
A. mellifera scutellata & Trace & $4.7 \pm 2.7$ & $25.0 \pm 5.0$ & $70.0 \pm 7.0$ & Zheng et al. (2010) \\
\hline
\end{tabular}

$\mathrm{HOB}=p$-hydroxybenzoate, 9-ODA=9-oxo-2 (E)-decenoic acid, HVA=4-hydroxy-3-methoxyphenylethanol, 9-HDA=9-hydroxy-2 $(E)$-decenoic acid, 10-HDAA=10-hydroxy-decanoic acid and 10-HDA=10-hydroxy-2 $(E)$-decenoic acid. Values are presented mean $\pm \mathrm{SD}$ to ease comparisons with previous studies 
honeybees which on average only had around $100 \mu \mathrm{g}$ of 9-ODA (Pankiw et al. 1996). This is very important and shows how conserved pheromones of the mandibular glands are in queens compared to those of workers. Recently, Van Oystaeyen et al. (2014) proposed that a conserved class of queen pheromones (mainly longchained hydrocarbons and esters in ants, wasps and bumble bees) were responsible for stopping worker reproduction. The expression of the chemical components of the queen pheromone in the different castes needs to be explored. Since if workers produce some 9-ODA and 9HDA under queen-right conditions, this may be a way to reduce the inhibitory effect of the queen pheromones on themselves and increase the effect on other workers (Moritz and Crewe, 2005), enabling these individuals to get a head start in the reproductive race if the colony becomes queenless.

Morphological characters revealed three morphoclusters that put workers from the North much closer to each other than those from the South West. The morphometric data also provided support for the pheromone data showing workers from the North West closer to those from the South.

We found differences in both proportions and absolute amounts from the head extracts of the mandibular gland pheromones and in morphometric characters of workers from the three regions sampled, with workers from South West being distinct from North Central and North West respectively. There are two possible propositions for this distinction based on pheromone profiles and morphometric characters. One is that there are possibilities that the workers from the South West are A. mellifera adansonii while those from the North Central could be hybrids between $A$. mellifera adansonii and $A$. mellifera jemenitica. Both our pheromone and morphometric data supported earlier work by Hepburn and Radloff (1998) which used morphometric and multivariate analysis to group honeybee workers from West Africa into three morphoclusters based on ecological and climatological characteristics. Thus, A. mellifera jemenitica in the sahelian and dry tropical zones, A. mellifera adansonii occurred in wet tropical and equatorial zones and hybrids between
A. mellifera adansonii and A. mellifera jemenitica were found in the savannah. However, this does not explain the differences we found between the pheromones of workers from the North Central and North West. Since the vegetation in Northern Central is guinea savannah whilst that from the North West is Sudan savannah (Rabiu et al., 2011).

Our second proposition is that all the workers are A. mellifera adansonii, and the differences we observed in the pheromone profiles and morphometrics are as a result of altitudinal, climatological as well as ecological differences between the regions. Indeed, Ruttner (1992) related the morphological differences among African subspecies to altitudinal, climatological as well as ecological parameters. Earlier work (see Mutsaers, 1991; Mbah and Amao, 2009; Ebenezer and Olugbenga, 2010) had also revealed different bee forage plants each for the South West, North West and North Central, Nigeria.

We have reported here a detailed account of the mandibular gland profiles from head extracts of $A$. mellifera adansonii workers from three ecological regions in Nigeria and have shown that these are similar qualitatively to those of A group subspecies. We further revealed compositional and quantitative differences in pheromone profiles as well as morphometric characters among honeybee workers from the different regions. We hypothesise, based on the pheromonal data, that pheromonal development and ovarian activation would be faster in the Northern populations compared to the southern ones. Also, that the values of both parameters will lie between that of A. mellifera capensis and A. mellifera scutellata, two neighbouring subspecies to the East and South. Our results also provide more insight into the nature and, to some extent, the variability present in the products from the exocrine glands of honeybees, thus supporting earlier evidence in the study of Crewe (1982) on how compositional variability serves as a key to social signals which cannot be ignored due to their importance in apiculture especially when the sustainable use of honeybee populations is a key requirement for food security. 


\section{ACKNOWLEDGMENTS}

The authors acknowledge Alhaji Idris Barau and Adamu Usman of the Beekeeping Extension Society, Zaria, Nigeria, for facilitating the sampling in Nigeria. Femi Kesington of Iwo Apiaries, Babatunde Oreyemi of Oyinladun Beekeepers Society Ijebu-Ode, Management of Roguwa Farms and other beekeepers for allowing us access to their apiaries. Habibu Aliyu, Ejuailo Dominic and Yusuf Shuaibu of the Department of Biological Sciences Ahmadu Bello University Zaria assisted with the morphometric measurements and logistics. Funding for this research was provided in part by the South African National Research Foundation (NRF) and University of Pretoria (2011 and 2012) and funding to AAY from the DST/NRF SARChI Chair in Mathematical Models and Methods in Bioengineering and Biosciences $\left(\mathrm{M}^{3} \mathrm{~B}^{2}\right)$ University of Pretoria (2013).

Contenus de la phéromone de la glande mandibulaire chez les ouvrières et les reines d'Apis mellifera adansonii

abeilles africaines / présence de reines / sécrétions / groupes de phéromones / morphogroupe

Der Gehalt an Mandibeldrüsenpheromon bei Arbeiterinnen und Königinnen von Apis mellifera adansonii

Afrikanische Honigbienen / weiselrichtig Mandibeldrüsensekretion / Pheromoncluster Morphocluster

\section{REFERENCES}

Basile, R., Pirk, C.W.W., Tautz, J. (2008) Trophallactic activities in the honeybee brood nest-Heaters get supplied with high performance fuel. Zoology 111 (6), 433-441

Brockmann, A., Dietz, D., Spaethe, J., Tautz, J. (2006) Beyond 9-ODA: sex pheromone communication in the European honey bee Apis mellifera L. J. Chem. Ecol. 32 (3), 657-667

Butler C., R. Callow, (1968) Pheromones of the honeybee (Apis mellifera L.): the "inhibitory scent" of the queen. Proc. R. Entomol. Soc. A: Gen. Entomol., 62-65.

Butler, C.G. (1959) The source of the substance produced by a queen honeybee (Apis mellifera) which inhibits development of the ovaries of the workers of her colony. Proc. R. Soc. B: Biol. Sci. 34, 137-138
Crewe R.M., (1982) Compositional variability: The key to the social signals produced by honeybee mandibular glands. The biology of social insects, 318-322

Crewe R.M., (1987) Lability of the mandibular gland signal of three races of African honey bees. Chemistry and Biology of Social Insects, Verlag J. Peperny, Munich, pp.433-434.

Crewe, R.M., Moritz, R.F.A. (1989) Variation in the components of head extracts of workers and queens of Apis mellifera intermissa Buttel-Reepen. Z. Nat.forsch 44, 590-596

Crewe, R.M., Velthuis, H.H.W. (1980) False queens: A consequence of mandibular gland signals in worker honeybees. Naturwissenschaften 67 , 467-469

Dietemann, V., Pflugfelder, J., Härtel, S., Neumann, P., Crewe, R.M. (2006) Social parasitism by honeybee workers (Apis mellifera capensis Esch.): evidence for pheromonal resistance to host queens' signals. Behav. Ecol Sociobiol 60 (6), 785-793

Ebenezer, I.O., Olugbenga, M.T. (2010) Pollen characterisation of honey samples from north central Nigeria. J. Biol. Sci. 10 (1), 43-47

Hepburn, H.R., Radloff, S.E. (1996) Morphometric and pheromonal analyses of Apis mellifera L. along a transect from the Sahara to the Pyrenees. Apidologie 27, 35-45

Hepburn, H.R., Radloff, S.E. (1998) Honeybees of Africa. Springer Verlag, Berlin, Germany

Johnson R.A., D.W. Wichern, (1998) Applied Multivariate Statistical Analysis, Prentice Hall, Upper Saddle River, New Jersey

Keeling, C.I., Otis, G.W., Hadisoesilo, S., Slessor, K.N. (2001) Mandibular gland component analysis in the head extracts of Apis cerana and Apis nigrocincta. Apidologie 32 (3), 243-252

Keeling, C.I., Slessor, K.N., Higo, H.A., Winston, M.L. (2003) New components of the honey bee (Apis mellifera L.) queen retinue pheromone. Proc. Nat. Acad. Sci USA 100 (8), 4486-4491

Le Conte, Y., Arnold, G., Trouiller, J., Masson, C. (1990) Identification of a Brood Pheromone in Honeybees. Naturwissenschaften 77, 334-336

Mbah C., A. Amao, (2009) Natural foods and feeding habits of the African honey bee Apis mellifera adansonii Latrielle (1804) in Zaria, northern Nigeria. Sci. World J. 4(1)

Moritz, R., Lattorff, H., Crewe, R. (2004) Honeybee workers (Apis mellifera capensis) compete for producing queen-like pheromone signals. Proc. R. Soc. B: Biol. Sci. 271, S98-S100

Moritz R.F.A., R.M. Crewe, (2005) The interplay of intracolonial genotypic variation and selforganisation of dominance hierarchies in honeybees, in: Hemelrijk C. (Ed.), Self-organisation and Evolution of Social Systems, Cambridge University Press, pp. 36-49. 
Mutsaers, M. (1991) Bees in their Natural environment in South Western Nigeria. The Nigerian Field 56, 3-18

Neumann, P., Hepburn, H.R. (2002) Behavioural basis for social parasitism of Cape honeybees (Apis mellifera capensi $\mathrm{s}$ ). Apidologie 33, 165-192

Pankiw, T., Winston, M.L., Plettner, E., Slessor, K.N., Pettis, J.S., Taylor, O.R. (1996) Mandibular gland components of European and Africanized honey bee queens (Apis mellifera L. ). J. Chem. Ecol., 22 (4): 605615

Pirk, C.W.W., Sole, C.L., Crewe, R.M. (2011) Pheromones. In: Radloff, S.E. (ed.) Hepburn R, pp. 207-214. Honeybees of Asia, Springer, Heidelberg, Dordrecht

Plettner, E., Otis, G.W., Wimalaratne, P.D.C., Winston, M.L., Slessor, K.N., Pankiw, T., Punchihewa, P.W.K. (1997) Species- and Caste-Determined Mandibular Gland Signals in Honeybees (Apis ). J. Chem. Ecol. 23 (2), 363-377

Rabiu, M.M., Gudlavalleti, M.V.S., Gilbert, C.E., Sivasubramaniam, S., Kyari, F., Abubakar, T. (2011) Ecological determinants of blindness in Nigeria: the Nigeria national blindness and visual impairment survey. S. Afr. Med. J. 101, 53-58

Ruttner, F. (1988) Morphometric Analysis and Classification. In: Ruttner, F. (ed.) Biogeography and Taxonomy of Honeybees. Springer Verlag, Berlin

Ruttner, F. (1992) Naturgeschichte der Honigbienen. Ehrenwirth, München

Ruttner, F., Hesse, B. (1981) Rassenspezifische Unterschiede in Ovarentwicklung und Eiablage von weisellosen Arbeiterinnen der Honigbiene Apis mellifera L. Apidologie 12 (2), 159-183

Simon, U.E., Moritz, R.F.A., Crewe, R.M. (2001) The ontogenetic pattern of mandibular gland components in queenless worker bees (Apis mellifera capensis Esch.). J Insect Physiol 47(7), 735-738
Slessor, K.N., Kaminski, L.-A., King, G.G.S., Borden, J.H., Winston, M.L. (1988) Semiochemical basis of the retinue response to queen honey bees. Nature 332, 354-356

Slessor, K.N., Winston, M.L., Le Conte, Y. (2005) Pheromone communication in the honeybee (Apis mellifera L.). J. Chem Ecol 31 (11), 2731-2745

Spannhoff, A., Kim, Y.K., Raynal, N.J.M., Gharibyan, V., Su, M.B., Zhou, Y.Y., Li, J., Castellano, S., Sbardella, G., Issa, J.P.J. (2011) Histone deacetylase inhibitor activity in royal jelly might facilitate caste switching in bees. EMBO reports 12 (3), 238-243

Tan, K., Yang, M., Wang, Z., Radloff, S.E., Pirk, C.W. (2012) The pheromones of laying workers in two honeybee sister species: Apis cerana and Apis mellifera. J. Comp. Physiol. A 198(4), 319-323

Van Oystaeyen, A., Oliveira, R.C., Holman, L., van Zweden, J.S., Romero, C., Oi, C.A., d'Ettorre, P., Khalesi, M., Billen, J., Wäckers, F. (2014) Conserved Class of Queen Pheromones Stops Social Insect Workers from Reproducing. Science 343 (6168), 287-290

Winston, M., Slessor, K., Willis, L., Naumann, K., Higo, H., Wyborn, M., Kaminski, L. (1989) The influence of queen mandibular pheromones on worker attraction to swarm clusters and inhibition of queen rearing in the honey bee (Apis mellifera L.). Insectes Soc 36 (1), 15-27

Winston, M.L., Slessor, K.N., Smirle, M.J., Kandil, A.A. (1982) The influence of a queen-produced substance, 9HDA, on swarm clustering behaviour in the honeybee Apis mellifera L. J. Chem. Ecol. 8, 5

Zheng, H.-Q., Dietemann, V., Crewe, R.M., Hepburn, R., Hu, F.-L., Yang, M., Pirk, C.W.W. (2010) Pheromonal predisposition to social parasitism in the honeybee Apis mellifera capensis . Behav. Ecol. 21 (6), 1221-1226 